\title{
胃癌における結腸合併切除の検討
}

\author{
癌研究会付属病院外科 \\ 太田 博俊早川 直和本原 敏司 \\ 金 使山本英昭 大橋一郎 \\ 高橋孝高木 国夫

\section{STUDIES OF COMBINED RESECTIONABLE CASES WITH COLON FOR CARCINOMA OF THE STOMACH}

\section{Hirotoshi OHTA, Naokazu HAYAKAWA, Toshiji MOTOHARA, Hitoshi KIM, Hideaki YAMAMOTO, Ichiro OHASHI, Takashi TAKAHASHI and Kunio TAKAGI} \\ Department of Surgery, Cancer Institute Hospital
}

\begin{abstract}
当外科における1973年までの胃癌結腸合併切除例は 394 例で胃癌手術例の $6.9 \%$ に相当する.これら結腸 合併切除例飞対し外科治療の立場から検討した．結腸および結腸間膜浸潤例は $28.3 \%$ 占め予後的浆膜面

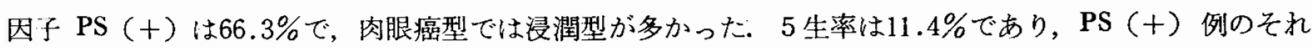
は23.5\%であり治癒切除例の 5 生率は32.9\%であった。疻着か浸潤かは肉眼的には判別しがたい場合があ り，癒着と判定した中に $9.8 \%$ は浸潤例があったために結腸癒着例または浸潤型の結腸間莫痹着例ならび に限局型でも癒着部分を切除後, 結腸への血行が保持できないような症例には積極的に合併切除すべきで あると考える。
\end{abstract}

索引用語 : 胃癌, 他缄器合併切除, 結腸合併切除

\section{I. はじめに}

胃診断学の進歩と胃集団検㟝のはばひろい展開によ り，早期胃癌が数多く発見され，胃癌に対する早期診 断，早期治療は現今では叮能になって来ているが，なお 日常の猃療に批いて進行した胃癌にも数多く遭遇し, 病 巣が胃のみにとどまらず，近接臓器へ波及している症例 に少なからず遭遇するのが現状である。かかる症例に対 し, 根治手術の目的のために他蔵器合併切除を必要とす る場合が少なくない，上部胃癌に対する膵尾側切除脾剔 出の合併手術, 下部胃癌で膵頭領域に瘑着浸潤した症例 に対する膵頭十二指腸切除術, 肝への愎着, 浸潤に対す る肝合併切除等がある。なかでも結腸あるいは結腸間膜 一浸潤，痹着した例に根治性のためには結腸合併切除が 必要になる。胃癌に批ける結腸合併切除術は他の臓器合 併切除に比して乎術手枝の上から容易であり, その根治
性む高く，適応もひろい。

癌研外科に打いて1946年より1973年までに結腸や結腸 間膜に浸潤，癒着した胃癌に対して，主として横行結腸 合併切除術を394例に施行した. 胃癌の結腸切除例につ いて肉眼所見, 手術所見, 組織所見ならびに予後などを 検討し, 胃癌に対する結腸合併切除の意義と適応につい

て検討した.

\section{II. 挨討症例}

i）胃癌に护ける結腸合併切除例（表 1 ）

1946年から1973年までに手術された胃癌は5,743例で, そのらち，394例 $(6.9 \%$ ) に結腸合併切除が施行され た. 治瘾切除例は258例, 非治瘾切除例飞終った症例は 136例で, 結腸合併切除の頻度は, 治虑切除例全体の6.4 \%, 非治癒切除例の $8.1 \%$ であた。直死例が 24 例 $6.1 \%$ であったが，多くは古い症例であり，肺炎，心不全が半 
表 1 胃癌に和汀る結腸合併切除例

\begin{tabular}{|c|c|}
\hline 男㿋手術列 & 5743 㨽 \\
\hline 結腸合併切除例 & $394(6.9 \%)$ \\
\hline 治癒切除例 & 258 \\
\hline 非治喻切除例 & 136 \\
\hline 直 死 例 & $24(6.1 \%)$ \\
\hline
\end{tabular}

表 2 肉眼癌型と占居部位

\begin{tabular}{|c|c|c|c|c|c|}
\hline & A & $\mathrm{M}$ & C & 全胃 & 計 \\
\hline 表在 & 2 & 2 & 0 & 0 & $\left(\begin{array}{c}4 \\
(1.0)\end{array}\right.$ \\
\hline 限局 & 89 & 46 & 8 & 8 & $\begin{array}{c}151 \\
(38.3)\end{array}$ \\
\hline 中間 & 22 & 19 & 4 & 1 & $\begin{array}{c}46 \\
(11.7)\end{array}$ \\
\hline 浸潤 & 91 & 49 & 8 & 45 & $\begin{array}{c}193 \\
(49.0)\end{array}$ \\
\hline 計 & $\begin{array}{c}204 \\
(51.8)\end{array}$ & $\begin{array}{c}116 \\
(29.4)\end{array}$ & $\begin{array}{c}20 \\
(5.1)\end{array}$ & $\begin{array}{c}54 \\
(13.7)\end{array}$ & $\begin{array}{r}394 \\
(100)\end{array}$ \\
\hline
\end{tabular}

数以上を占め最近では，ほとんど経験していない。

近年, 胃診断学の進歩により早期胃癌が多く見い出さ れてきているが，他蔵器まで浸潤している進行胃癌は減 少傾向にあるのではないかと考兄られ勝ちであるが，進 行度で年次的に stage 別の頻度をみても, 切除胃癌の stage IVの頻度に有意差はなく, 結腸合併切除を施行し ない限り根治性が得られない症例は，5年每に区切。 てみても $5 \sim 8 \%$ に以前と変りなく同程度に手術されてい， る.

ii）肉眼癌型と占居部位（表 2）

結腸合併切除を行った胃癌の肉眼癌型の頻度をみる と，浸潤型が193例 $(49.0 \%)$ と多く，次いで限局型151
例 $(38.3 \%)$ ，中間型46例 $(11.7 \%)$ であり，表在型が 4 例 (1\%) 含末れていた. 一般胃癌 (対照例) の分類 と比較してみると ${ }^{1)}$, 浸潤型 $41.7 \%$ ，限局型 $29.0 \%$ ，中 間型 $12.2 \%$ ，表在型 $17.1 \%$ であり，結腸合併切除例は比 較的限局型が多く認められた．表在型 4 例の結腸合併切 除の理由は，幽門下転移リンパ節が，結腸間膜と強く癒 着していたためであった４例とも非治瘾切除で, 肝転 移 2 例, 腹膜播種 1 例, 広沉なりン八゙節転移 1 例であっ た.

占居部位別にみると，胃下部に204例（51.8\%），胃 中部116例 $(29.4 \%)$, 胃上部 20 例 $(5.1 \%)$, 全胃54例 （13.7\%）であった． 結腸合併切除例は解剖学的にも胃 下部，中部に多いのは当然であるが，胃上部癌において む結腸や結腸間膜が胃上方の癌巣に引きつけられ癒着, 浸潤していたがために合併切除された。

iii）結腸合併切除の理由（表 3 )

結腸合併切除の理由について，手術時の肉眼所見をみ ると，胃癌が横行結腸壁へ直接波及する場合よりは，結 腸間膜に浸潤または忿着し結腸間膜切除にともなら血行 障害による結腸合併切除となったものが多く，その他に 主病巣でなく幽門下転移りン：節が結腸間膜と癒着また は浸潤しているためのものが少数であるが認められた。

これらを組織学的に検索してみる. 主病巣が結腸およ び結腸間膜に浸潤していたもの73例 $(28.3 \%)$, 結腸へ㾻 着していたもの39例 $(15.1 \%)$ ，結腸間膜へ癒着してい たもの137例 $(53.1 \%)$ ，幽門下転移リンバ節が結腸間膜 に癒着していたもの 9 例 (3.5\%) で，治瘾切除例の約 $30 \% か ゙$ 結腸および結腸間膜浸潤例であった。合併切除の 理由を肉眼癌型別にみると, 結腸拉よび結腸間膜浸潤例 の肉眼癌型は浸潤型が68.5\%（50/73）と多かったが，

表 3 結腸合併切除の理由(治瘉切除例)

\begin{tabular}{|c|c|c|c|c|c|c|}
\hline & \multirow{2}{*}{ 例数 } & \multicolumn{5}{|c|}{ 肉 眼 癌 型 } \\
\hline & & \multicolumn{2}{|c|}{ 限局型 } & 中間型 & \multicolumn{2}{|c|}{ 浸潤型 } \\
\hline $\begin{array}{c}\text { 結腸, 結腸間膜へ浸潤 } \\
(\text { si, sei) }\end{array}$ & $\begin{array}{c}73 \\
(28.3)\end{array}$ & 13 & & 10 & 50 & 8.5) \\
\hline 結 腸 $(\mathrm{se}$ 以内) 癒 着 & $\begin{array}{c}39 \\
(15.1)\end{array}$ & 19 & \multirow{2}{*}{$(54.5)$} & 2 & 18 & \multirow{2}{*}{$(35.8)$} \\
\hline 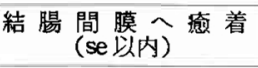 & $\begin{array}{c}137 \\
(53.1)\end{array}$ & 77 & & 15 & 45 & \\
\hline $\begin{array}{c}\text { 幽門下転移リンパ節が } \\
\text { 結 腸 間 膜 息 着 } \\
\text { (se以内) }\end{array}$ & $\left(\begin{array}{c}9 \\
(3.5)\end{array}\right.$ & \multicolumn{2}{|l|}{7} & 1 & \multicolumn{2}{|l|}{1} \\
\hline
\end{tabular}


結腸および 結腸間膜へ癒着のみにとどまっている例で は, 限局型が54.5\% (19+77/39+137) で，浸潤型の $35.8 \%(18+45 / 39+137)$ に比して, やや多い傾向を示 した.なお，幽門下転移リンパ節が結腸間膜と㾤着して いた 9 例中 7 例が限局型癌であった。

iv) 肉眼的浆膜浸潤度と組織学的深達度

胃癌病巣に結腸や結晹間膜がひきつけられ固定してい る場合に癌浸潤によるものか瘾着のみかの肉眼的判定は 困難な場合があって, 肉眼的深達度診断々組織学的深達 度のそれとの関連についての検討が必要となる．治虑切 除例について肉眼的禁膜浸潤度と組織学的深達度との関 連をみると（表 4 ), $\mathrm{S}_{0}$ では $\mathrm{pm}, \mathrm{ss} \alpha, \mathrm{ss} \beta$ が23例（82.1 \%)でその一致率は高いが， $\mathrm{S}_{1}$ では ss $\gamma$ が18例であっ たが，ss $\alpha ，$ ss $\beta$ が32例と多かった. $\mathrm{S}_{2}$ では， se が25例 (35.7\%) と両者の深達度の一致率は低く, pm, ss $\alpha$. $\beta \cdot \gamma$ が36例 (51.4\%) と多かった. $\mathrm{S}_{3}$ では si, sei が

表 4 肉眼的槳膜浸潤度之組織学的深達度 （治癒切除例）

\begin{tabular}{|c|c|c|c|c|c|c|}
\hline & & $S_{0}$ & $\mathrm{~S}_{1}$ & $\mathrm{~S}_{2}$ & $\mathrm{~S}_{3}$ & 計 \\
\hline \multirow{2}{*}{$\begin{array}{c}\text { PS } \\
(-)\end{array}$} & $\mathrm{Pm}$ & 3 & 4 & 2 & 2 & 11 \\
\hline & $\operatorname{ss} \alpha \cdot \beta$ & 20 & 32 & 16 & 8 & 76 \\
\hline \multirow{3}{*}{$\begin{array}{r}\text { PS } \\
(+)\end{array}$} & $\operatorname{ss} r$ & 4 & 18 & 18 & 6 & 46 \\
\hline & se & 1 & 4 & 25 & 22 & 52 \\
\hline & si, sei & 0 & $7^{*}$ & $9^{*}$ & 57 & 73 \\
\hline & 計 & 28 & 65 & 70 & 95 & 258 \\
\hline
\end{tabular}

57例 $(60 \%)$ で両者の一致率は高かった.

肉眼的ならびに組織学的深達度との食い違いをみる と，太い枠で囲んだ110例 (42.6\%) は組織学的潹達度 に比べて 肉眼的浆膜浸潤度を深く読み過ぎて, 特に結 腸や結腸間膜に浸潤していると判断した $\mathrm{S}_{3}$ 95例中38例 （40\%) は組織学的には浸潤していなかった。 また斜線 の枠で曲んだ25例 $(9.7 \%)$ は肉眼的浆膜浸潤度よりも 組織学的深達度の方が深く，とくに星印の16例 $(9.8 \%$, $16 / 163\left[\mathrm{~S}_{0}\right.$ 以下の計]) は肉眼的には癒着と判断してい たが組織学的検索の結果, 結腸または結腸間膜への浸潤 例であったことは留意すべきことである，予後的浆膜面 因子 ps (+) 例は258例中，計171例 $(66.3 \%)$ で，約 7 割近い症例は, 結腸合併切除の絶対的適応であった.

肉眼的に浆膜浸潤がないとされた $\mathrm{S}_{0} 28$ 例洁腸合併 切除がなされた理由についてみると（表 5 )，24例が胃 の方へ大網が引きつけられ, 結腸や結腸間膜に癒着し,
表 $5 \quad \mathrm{~S}_{0}$ 28例の結腸合併切除の理由

\begin{tabular}{|c|c|c|}
\hline \multirow{3}{*}{\multicolumn{2}{|c|}{$\begin{array}{l}\text { 結腸間膜に稷着 } \\
\text { 結腸に癒着 } \\
\text { 幽門下転移リンハ節が結腸間膜に癒着 }\end{array}$}} & \multirow{3}{*}{$\begin{array}{r}21 \\
3 \\
4\end{array}$} \\
\hline & & \\
\hline & & \\
\hline 限局型 & \multicolumn{2}{|c|}{$25(89.3 \%)$} \\
\hline 中間型 & \multicolumn{2}{|c|}{2} \\
\hline 浸潤型 & \multicolumn{2}{|l|}{1} \\
\hline $\mathrm{Pm}$ & \multicolumn{2}{|c|}{$3(10.7 \%)$} \\
\hline $\operatorname{ss} \alpha \cdot \beta$ & \multicolumn{2}{|c|}{$20(71.4 \%)$} \\
\hline ss $\gamma$ & \multicolumn{2}{|c|}{$4(14.3 \%)$} \\
\hline se & \multicolumn{2}{|c|}{$1(3.6 \%)$} \\
\hline
\end{tabular}

表 6 手術々式 $(1946 \sim 1973)$

\begin{tabular}{|c|c|}
\hline 幽閒側切除十結腸切除 & 190 \\
\hline 幽閏側切除十結腸切除 +P. D. & 43 \\
\hline 青 全 剔 除十結腸切除 & 27 \\
\hline 胃全剔 除十結腸切除+P.S. & 131 \\
\hline 留全剔除十結腸切除+P.D. & 2 \\
\hline 噴門側切除十結腸切除+P.S. & 1 \\
\hline 計 & 394 \\
\hline
\end{tabular}

結腸を温存し剖離することが不能であり，4例は幽門下 転移リソパ節が結腸間膜に瘾着して剝離不能のために合 併切除が施行された. 肉眼癌型では28例中25例 (89.3 \%) が限局型であった.

v) 手術々式 (表6)

結腸合併切除が行われた胃癌症例の手術々式は表 6に 示す.

幽門側切除例が233例 $(59.1 \%)$ で，そのうち膵頭十 二指腸切除に結腸合併切除が行われたものが 43 例 (10.9 \%)であった. 胃全剔例では結腸扣よび脺尾脾合併切除 が131例 (33.2\%) と多く行われた. 結腸合併切除394例 の直接死亡例は 24 例 $(6.1 \%)$ で, 結腸切除後の吻合部 の縫合不全に起因したと考克られる死亡例は 3 例であっ た. 従来, 私どもは結腸の吻合は, 腸管壁がうすくから 小腸に比べて血行が不良であること, 胃癌手術に際し結 腸合併切除の前準備が十分に行われてないこと, また術 後ガスによる膨満などの悪条件があることから，縫合不 全防止のために重積様端々物合を考案し実施してきた。 近年, 胃中部㧍よび下部大弯側に主病巣を有する場合の 進行胃癌手術に際しては, 術前, 注腸検査に上る結腸へ の浸潤の有無を見, 浸潤を疑われるのはもちろん, たと 方結腸への浸潤のない場合でも, 結腸内腔の清浄と腸内 
表 7 深達度別 5 年生存率（治癒切除例）

\begin{tabular}{|c|c|c|c|c|c|}
\hline & 症 例 & 直死例 & 5生例 & 耐術 5 生率 & PS \\
\hline $\mathrm{Pm}$ & 11 & 0 & 5 & $45.5 \%$ & \multirow{2}{*}{$\begin{array}{l}\text { PS (-) } \\
51.2 \%\end{array}$} \\
\hline $\operatorname{ss} \alpha \cdot \beta$ & 76 & 3 & 38 & $52.1 \%$ & \\
\hline $\operatorname{ss} r$ & 46 & 2 & 16 & $36.4 \%$ & \multirow{3}{*}{$\begin{array}{l}\text { PS (+) } \\
23.5 \%\end{array}$} \\
\hline se & 52 & 4 & 14 & $29.2 \%$ & \\
\hline si, sei & 73 & 3 & 8 & $11.4 \%$ & \\
\hline 計 & 258 & 12 & 81 & \multicolumn{2}{|c|}{$32.9 \%$} \\
\hline
\end{tabular}

PS : 予後的浆膜面因子

表 8 深達度別 5 生耐術率（治劄切除例）

\begin{tabular}{|c|c|c|}
\hline & 結腸合併切除例 & 対 照 例 \\
\hline $\mathrm{Pm}$ & $5 / 11 \quad(45.5)$ & $256 / 356 \quad(71.9)$ \\
\hline $\operatorname{ss} \alpha \cdot \beta$ & $38 / 73 \quad(52.1)$ & $519 / 1024(50.7)$ \\
\hline ss $r$ & $16 / 44 \quad(36.4)$ & $200 / 460 \quad(43.5)$ \\
\hline se & $14 / 48 \quad(29.2)$ & $127 / 547 \quad(23.2)$ \\
\hline si, sei & $8 / 70(11.4)$ & $15 / 289 \quad(5.2)$ \\
\hline 計 & $81 / 246(32.9)$ & $1117 / 2676(41.7)$ \\
\hline
\end{tabular}

表 9 リンパ節転移別 5 年生存率

\begin{tabular}{|c|c|c|}
\hline & 結腸合阱比陸例 & 対 胎 例 \\
\hline n $\quad(-)$ & $34 / 57 \quad(59.6 \%)$ & $813 / 1016(80.0 \%)$ \\
\hline $\mathrm{n}_{1}(+)$ & $32 / 90 \quad(35.6 \%)$ & $455 / 863 \quad(52.7 \%)$ \\
\hline $\mathrm{n}_{2}(+)$ & $14 / 93(15.1 \%)$ & $247 / 967 \quad(25.5 \%)$ \\
\hline $\mathrm{n}_{3}(+)$ & $1 / 6 \quad(16.7 \%)$ & $24 / 240 \quad(10.086)$ \\
\hline 計 & $81 / 246(32.9 \%)$ & $1539 / 3086(49.9 \%)$ \\
\hline
\end{tabular}

耐術治瘉切除例

細菌に対する抗生剤投与を行らことにより，1976年から は重積様吻合ではなく結腸端々層々吻合に变劣ても縫合 不全は，ほとんど認められなくなった。

iv) 5 年生存率 (表 $7,8,9,10)$

結腸合併切除が行われた胃癌症例（以下合切例之略） の予後を結腸合併切除の必要のない一般胃癌 (以下対照 例と略）と対比して, 深達度, リンバ節転移, stage 分 類で，いかなる差違があるか比較検討してみた。

深達度別ならびに予後的浆膜面因子で，その予後をみ ると, $\mathrm{pm}$ 例の耐術 5 年生存率 $455.5 \%, \mathrm{ss} \alpha, \mathrm{ss} \beta$ は $52.1 \%$ すなわち ps（一）例は $51.2 \%$ で ssてでは $36.4 \%$ ， se は29.2\%, si, sei では11.4\%であり ps (十) 例は
表10 Stage 別 5 生率

\begin{tabular}{|c|c|c|}
\hline & 結腸合併切除例 & 対 照 例 \\
\hline stage I & $20 / 30(66.7 \%)$ & $646 / 725(89.1 \%)$ \\
\hline II & $38 / 96 \quad(39.6 \%)$ & $659 / 1212(54.4 \%)$ \\
\hline III & $15 / 50(30.0 \%)$ & $215 / 904 \quad(23.8 \%)$ \\
\hline IV & $8 / 70(11.4 \%)$ & $19 / 245(7.7 \%)$ \\
\hline 計 & $81 / 246(32.9 \%)$ & $1539 / 3086(49.9 \%)$ \\
\hline
\end{tabular}

$23.5 \%$ であった. 対照例と比較してみると, $\mathrm{pm}$ 例抢よ びss $\gamma$ 例に招いて合切例の方が予後不良であったが症 例数に差があるので有意の差をい学ないが，再者の差は 深達度以外の因子が少なからす影響を及活していると考 えられる，他臟器浸潤例に执いては，合切例の方が対照 例に比べて予後は良好であった．では深達度以外に予後 に及ぼす因子がリンパ節転移程度でみられるかどらかみ てみる（表9）。全体からみると合切例の方が対照例よ りも5 年生存率は低いか，それは対照例法移陰性例早 期癌症例が入っているためであり， $\mathrm{n}_{2}(+), \mathrm{n}_{3}(+)$ に なるとその差はなく， $\mathrm{n}_{3}$ (十）にいたってはむしろ合切 例の方が良い。

stage 分類別で， stage I， IIでは対照例の方が予後 は良いが，III，IVでは逆汇合切例の方が良く，上向きの 傾向を示していた，すなわち，結腸や結腸間膜に浸潤し ている胃癌に対して積極的に結腸合併切除を行えば，よ り良好な予後が期待できるとい方よう。

表11 結腸合併切除の予後（治瘾切除例）

\begin{tabular}{|c|c|c|c|c|}
\hline & \multirow{2}{*}{$\begin{array}{l}5 \text { 年率 } \\
(\%)\end{array}$} & \multicolumn{3}{|c|}{ 肉＼cjkstart眼＼cjkstart癌 } \\
\hline & & 限局型 & 中間型 & 浸潤型 \\
\hline 結腸，結腸間膜へ浸潤 & $\begin{array}{l}8 / 70 \\
(11.4)\end{array}$ & $\begin{array}{l}4 / 12 \\
(33.3)\end{array}$ & $\begin{array}{l}1 / 10 \\
(10.0)\end{array}$ & $\begin{array}{c}3 / 48 \\
(6.3)\end{array}$ \\
\hline 結 腸 へ 瘉 着 & $\begin{array}{l}13 / 35 \\
(37.1)\end{array}$ & $\begin{array}{l}11 / 17 \\
(64.7)\end{array}$ & $0 / 2$ & $\begin{array}{l}2 / 16 \\
(12.5)\end{array}$ \\
\hline 結腸 間膜へ癒着 & $\begin{array}{l}56 / 132 \\
(42.4)\end{array}$ & $\begin{array}{l}39 / 76 \\
(51.3)\end{array}$ & $\begin{array}{c}5 / 15 \\
(33,3)\end{array}$ & $\begin{array}{l}12 / 41 \\
(29.3)\end{array}$ \\
\hline $\begin{array}{l}\text { 幽門下軽移リンパ節か } \\
\text { 結 腸 間 膜 と瘉 着 }\end{array}$ & $\begin{array}{l}4 / 9 \\
(44.4)\end{array}$ & $\begin{array}{l}4 / 7 \\
(57,1)\end{array}$ & $0 / 1$ & $0 / 1$ \\
\hline 計 & $\begin{array}{l}81 / 246 \\
(32.9)\end{array}$ & $\begin{array}{l}58 / 112 \\
(51.8)\end{array}$ & $\begin{array}{l}6 / 28 \\
(21.4) \\
\end{array}$ & $\begin{array}{l}17 / 106 \\
(16.0)\end{array}$ \\
\hline
\end{tabular}

（）\%耐術例

結腸および結腸間膜への進行程度の予後を肉眼癌型別 にみた時（表11）, 各項目とも, 中間型, 浸潤型に比べ て限局型の予後は良く浸潤例の限局型でも $33.3 \%$ の 5 年 生存率を得ている。とく幽門下転移リンパ節が結腸間 膜之瘾着した症例では限局型で $57.1 \%$ の 年生存率を得 
表12 胃癌の結腸合併切除例（治癒切除例）

\begin{tabular}{l|r|r|r}
\hline \hline & 5 生例 81 例 & 非 5生 177例 & si, sei 73例 \\
\hline 限局型 & $58(71.6)$ & $57(32.2)$ & $13(17.8)$ \\
\hline 中間 型 & $6(7.4)$ & $22(12.4)$ & $10(13.7)$ \\
\hline 浸 潤 型 & $17(21.0)$ & $98(55.4)$ & $50(68.5)$ \\
\hline \hline $\mathrm{n}_{0}(-)$ & $34(42.0)$ & $25(14.1)$ & $13(17.8)$ \\
\hline $\mathrm{n}_{1}(+)$ & $32(39.5)$ & $62(35.0)$ & $17(23.3)$ \\
\hline $\mathrm{n}_{2}(+)$ & $14(17.3)$ & $84(47.5)$ & $39(53.4)$ \\
\hline $\mathrm{n}_{3}(+)$ & $1(1.2)$ & $6(3.4)$ & $4(5.5)$ \\
\hline $\mathrm{Pm}$ & $5(6.2)$ & $6(3.4)$ & \\
\hline ss $\alpha \cdot \beta$ & $38(46.9)$ & $38(21.5)$ & \\
\hline ss $r$ & $16(19.8)$ & $30(16.9)$ & \\
\hline se & $14(17.3)$ & $38(21.5)$ & \\
\hline si, sei & $8(9.9)$ & $65(36.7)$ & \\
\hline
\end{tabular}

( ) $\%$ C.I.H

た。

種々の因子別に胃癌の結腸合併切除例について検討し て来たが，ここで治癒切除例の 5 年生存例， 5 年以内死 亡例（非 5 生例と略）さらに結腸や結腸間膜浸润例（以 下浸潤例，si，sei と略）についてまとめた（表12）.

肉眼癌型では， 5 生例は限局型が71.6\%と多く，非 5 生例では浸潤型が $55.4 \%$ と多く, si， sei 例では浸潤型 の比率はさらに増え68.5\%であった。 またリンパ節転 移では，5生例では $\mathrm{n}(-)$ が一番多く， $\mathrm{n}(-)$ と $\mathrm{n}_{1}$ (十）で81.5\%と大半を占めているが，非 5 生例ではそ のピークは $\mathrm{n}_{2}(+)$ に移り, si, sei 例化いたっては $\mathrm{n}_{2}$ （十）の 比率が半数を越光るようになり，5生例とはま ったく逆の比率になってくる.

深達度の比較では， 5 生例飞 ps (-) 例が多く非 5 生例では ps（十）例が70\%以上と多くなっていた.

不幸にして再発をきたした例（表13）では，腹膜播種 が一番多く $34.5 \%$ を占め, ついで肝転移，局所再発の順 である．また結腸合併切除を行った症例の中で，非治癒 切除に終ったのが136例あるが，その内訳（表14）は， 腹膜播種（p 因子） が69例 $(50.8 \%$ ) と半数以上を占 め，次いでリンハ節転移（n因子） 57 例 (41.9\%) であ

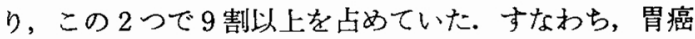
の結腸技よび結腸間膜瘾着浸潤例では，予後的楽膜面因 子そ机に $\mathrm{p}$ 因子が予後に及ぼす重要な因子であるとい えよう。

最後に結腸合併切除例の予後をまとめた（表15），治
表13 再発形式

\begin{tabular}{|c|c|}
\hline 腹膜播種 & $38(34.5 \%)$ \\
\hline リンパ節転移 & $5(4.5 \%)$ \\
\hline 局所再発 & $11(10.0 \%)$ \\
\hline 肝転移 & $17(15.6 \%)$ \\
\hline 肺転移 & $5(4.5 \%)$ \\
\hline 悪液質 & $1(0.9 \%)$ \\
\hline 㾔死（部位不明） & $33(30.0 \%)$ \\
\hline
\end{tabular}

表14 結腸合併切除（非治癒切除例）

\begin{tabular}{lr}
\hline P因子 & $69(50.8 \%)$ \\
H因子 & $9(6.6 \%)$ \\
n因子 & $57(41.9 \%)$ \\
aw $(+)$ & $1(0.7 \%)$ \\
\hline & $136(100 \%)$ \\
\hline
\end{tabular}

表15 胃癌における結腸合併切除例

\begin{tabular}{|c|c|c|c|c|}
\hline & \multicolumn{2}{|c|}{ 治雀切除（258） } & \multicolumn{2}{|c|}{ 非治癒切除 (136) } \\
\hline & 絶対 & 相対 & 相対 & 絶対 \\
\hline 症例数 & 146 & 112 & 94 & 42 \\
\hline 直死例 & 6 & 6 & 9 & 3 \\
\hline 5 生例 & 64 & 17 & 1 & 0 \\
\hline \multirow{2}{*}{ 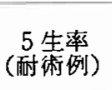 } & $45.7 \%$ & $16.0 \%$ & $1.2 \%$ & $0 \%$ \\
\hline & \multicolumn{2}{|c|}{$32.9 \%$} & \multicolumn{2}{|c|}{$0.8 \%$} \\
\hline
\end{tabular}

癒切除258例中， 5 年生存例 は81例で，耐術 5 年生存率 は32.9\%である．絶対治㾤切除例のそれは $45.7 \%$ と良い が，相対治癒切除例では，16\%と低值を示した．非治癒 切除例136例中，相対非治癒切除例飞 1 例の 5 生例を得 ているが，本例は横行結腸に近接した大網の播種性転移 に対し結腸合併切除に上り 5 生した症例であった。

\section{III. おわりに}

進行胃癌で他蔵器に浸潤瘾着している症例に対する治 瘾手術すなわち他臓器合併切除術は術前術後の管理の向 上，各手術手枝の向上により安全となり，年龄的制限も 除去されて来ている.1976年の第26回胃癌研究会におい て「胃癌の他藏器合併切除の問題点」と題して，その意 義，適応，治療，予後などについて多くの施設から研究 発表がなされ2)，われわれる「胃癌における膵頭十二指 腸切除術」 ${ }^{3)}$ 「膵尾脾合併切除の遠隔成續」と題して研 究発表をした．また1979年第14回日本消化器外科学会総 会においても, シンポジゥムで「進行胃癌における周囲 贜器合併切除の意義」と題して，とくに膵脾合併切除に 
ついて活発な討論が展開されだ/5)。このように単に胃 切除に終わらず周团臟器合併切除についての意義が再検 討されるよらになっだ．

今回われわれは胃癌に対する結腸合併切除例の意義と 適応について検討を加えた。

当外科注ける胃癌の結腸合併切除例は394例で，同 期間の胃癌手術例の6.9\%に相当する. 他の施設 ${ }^{2}$ 飞お いてす $2 \sim 45$ 例 $(0.3 \sim 4,7 \%)$ に合併切除が施行されて いる. 治窉切除例は 258 例，その切除率は65.5\%で，35 \%近くは非治陭切除に終っている. 症例数からみれば浸 潤型が多かったが, 対照例との比較では限局型が多かっ た.

合併切除の理由には大別して，3つをあげることがで きる.

i ）胃癌が結腸や結腸間膜に浸潤しているために根治 性を求める意味で合併切除したもの.

ii）結腸や結晹間膜に疻着しているだけであっても, 結腸間膜との癒着の場合, その部を切除することたよ り, 結腸への血行が保持出来ず，ために結腸合併切除を 二次的理由により施行したもの.

iii）治瘾切除にはならないが，合併切除しなければ早 晚，腸狭窄を来たすために合併切除をしたもの.

治癒切除例に拈计る結腸合併切除の組織学的検索の結 果, 予後的浆膜面因子 ps (t) 例飞幽門下転移りンパ 節が結晹間膜につよく瘑着している例を加えると，70\% 近くの症例は, 合併切除の意義があり, 結腸合併切除の 適応例であったと考えられた．ただ今回の検討症例の中 に，肉眼的に瘾着のみと考えられた症例でも浸濉例があ ったことに関しては留意すべさである．さらにこれらの 予後を見た時，合併切除を用い，肉眼的に治癋切除がな されたにもかかわらず腹腹播種の再発形式をとったもの が多く認められた。

\section{IV.むすひ}

1. 結腸合併切除例の頻度は手術胃癌の $6.9 \%$ であり，

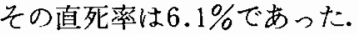

2. 胃癌の結腸および結腸間膜への癋着か、浸潤かは肉 眼的判別にむずかしい場合があり，瘉着とした症例中で も9.8\%に浸潤例があった。

3. 肉眼癌型からみて，浸潤型は結腸および結腸間膜 への浸潤例が多く，限局型は癒着にとどまるものが多か った.

4. 治瘾切除例にお括るる結腸および結腸間膜への組織 学的浸潤例は28.3\%であったが，予後的浆膜面因子 ps （十）例は66.3\%であった。

5. 治瘾切除例の 5 年生存率は $32.9 \%$ であり, 結腸掠 上び結腸間膜漫潤例の 5 年生存率は $11.4 \%, \mathrm{ps}(+)$ 例 では23.5\%，ps（一）例では51.2\%であった.

以上より胃癌の結腸および結腸間膜への浸潤ならびに 結腸瘾着例に対しては結腸合併切除を行い，間膜への癒 着と判断しても，主病巣の肉眼癌型が浸潤型ならば合併 切除を行い，限局型であれば，瘾着間膜を広く切除し， 結腸への血行が保持不可能であれば結腸合併切除を積極 的にすべきと考光る.

本論文の要旨は第14回日本消化器外科学会総会におい て発表した。)

\section{文献}

1）暒谷 鐸，高木国夫：胃癌根治乎術とその遠隔 成樍。外科治療, 39：679-685, 1978.

2）第26回胃癌研究会プロダラム、1976.1.

3）太田博俊, 高木国夫他：胃癌に求ける膵頭十二 指腸切除術。癌の䠛床, $23: 452-457,1977$.

4) 第14回日本消化器外科学会総会プログラム。 日 消外会誌, $12(6) ： 36 ， 1979$.

5) 大橋一郎, 高木国夫, 太田博俊他：進行胃癌に 叔什る膵脾合併切除の意義一特にリンパ節転移 について一. 日消外会誌, 12 (12): 993-999， 1979.

6) 高木国夫, 大橋一郎, 太田博俊 : 進行胃癌に 対する他臟器合併切除の意義. 消化器外科, 3 (1) : 45-53, 1980 . 